ISSN: 0210-7287

DOI: https://doi.org/10.14201/16162020107190

\title{
NOCHES BLANCAS: UN DISCURSO POÉTICO
}

\section{White nights: a Poetic Discourse}

\author{
Serena Russo \\ Universidad de Granada \\ serenarusso84@hotmail.it
}

Recibido: enero de 2020; Aceptado: marzo de 2020; Publicado: diciembre de 2020 Ref. Bibl. SERENA RUSSO. NOCHES BLANCAS: UN DISCURSO POÉTICO. 1616: Anuario de Literatura Comparada, 10 (2020), 71-90

RESUMEN: Este trabajo analiza la relación entre poesía y cine, investigando dentro de la más amplia tradición de relaciones entre palabra e imagen y, más concretamente, en el concepto de adaptación. De hecho, en la trasposición de una novela a la pantalla el cine se ha centrado casi siempre en los aspectos narrativos. Sin embargo, en este artículo queremos demostrar la existencia de un cine que destaca por no conectar directamente con la narratividad, sino con un diferente nivel artístico menos convencional. Partimos, pues, de un cine que llamamos poético, no necesariamente enlazado con la época de las vanguardias, sino que ha de buscarse también en la obra de algunos directores del cine moderno. Nos centraremos en la obra del director italiano Luchino Visconti, y, en concreto, en la película Noches blancas, que manifiesta en su estructura y en su forma un lenguaje diferente que podemos calificar como poético. A lo largo de las siguientes páginas iremos definiendo el concepto de poeticidad a partir del análisis de esta obra fílmica.

Palabras clave: cine; poesía; cine poético; Noches Blancas; Luchino Visconti.

ABSTRACT: This article analyzes the relationship between poetry and cinema, inestigating in the largest tradition of relations between word and image and especially in the concept of adaptation. Actually, the transposition of the novel to 
the screen delivered to the cinema a narrative aspect since always. Nevertheless, in this article we want to demonstrate the presence of a cinema that highlights for not to be connected directly to the narrativity, but to a differet artistic level less conventional. We have recognized the presence of a cinema that we call poetic, not necessarly linked to the vanguards, but that has to be researched also in the Works of some modern cinema's directors. We put he attention on the Italian director Luchino Visconti, and especially on the film White nights, that manifest in its structure and in its shape a different language and, for that reason, we consider it as poetic. In this work we are going to highlight the concept of poetic analyzing this film.

Keywords: Cinema; poetry; poetic cinema; White nights; Luchino Visconti.

\section{INTRODUCCIÓN}

Dentro del marco de los estudios de las relaciones entre cine y literatura que parten, casi siempre, de la constatación de las analogías del primero con el teatro y la novela, como géneros con un gran potencial narrativo y propensión a contar historias, también ha de atenderse a las especificidades del cine como lenguaje, a las diferencias que lo identifican como medio, más allá de los procedimientos o elementos que pueda compartir con otras artes. Esta institucionalización narrativa y mimética del cine puede suponer una limitación en la recepción cuando se interpreta una película exclusivamente desde una concepción narrativo-representativa de la realidad, sin considerar el hecho de que esta misma obra puede contener características que se alejen de este tipo de «lectura». Gilles Deleuze (1984 y 1987), habla de dos tipos de imagen en el cine: la imagen-movimiento y la imagentiempo, La primera considera la percepción de estas mismas imágenes en acción a través del movimiento; es la imagen del desenvolvimiento lógicoracional y lineal de los eventos, donde predomina este concepto de causaefecto. Esta "mecánica» funciona teniendo en cuenta que, respecto a unas situaciones, intervienen unas fuerzas externas que provocan la acción y que, en consecuencia, transforman la situación. Estas acciones nos llevan a percibir solo lo que nos interesa percibir.

La segunda, la imagen-tiempo ${ }^{1}$, no es una consecuencia lineal de la situación, ya que hay un cambio cualitativo que va más allá del movimiento

1. La imagen-tiempo es la que encontramos aquí como recurso poético, es decir, como una unión de lo que es la imagen real que el poema quiere expresar y la imagen virtual que representa. Como hemos dicho antes, esta imagen funciona de forma autónoma y 
y que se acerca al concepto de tiempo en su estado más puro, sin seguir un modelo preciso, pues se trata de imágenes de distinta derivación y naturaleza; además, no hay un esquema lógico, sino simplemente dos polos que se oponen y actúan enfrentándose continuamente, como lo objetivo/ subjetivo o lo real/imaginario. Este tipo de imagen es completamente independiente de cualquier subordinación narrativa. Mientras en la primera los personajes se adaptan al ambiente, a la historia y a las acciones, en la segunda los protagonistas son ya de por sí "tiempo», es decir, se pierden en el ambiente y marcan su presencia respecto a él. Una diferencia de la que nos habla Deleuze es la presencia del montaje, que en el primer caso se esconde y en el segundo se pone en evidencia para un espectador que puede "sentir" su presencia.

Esta idea de imagen-tiempo es la que, según este artículo, más se acerca a un tipo de cine "distinto", y con este adjetivo nos referimos a su aspecto menos narrativo, donde la historia y la estructura están menos conectadas al concepto de causa-efecto, para ofrecer una mirada diferente sobre lo que llamamos película. Ha habido, a lo largo del siglo xx, una serie de directores que han defendido y practicado especialmente este tipo de cine, entre los cuales encontramos a Jean-Luc Godard o Alain Resnais. Considerando este punto de partida, nos hemos planteado la pregunta: ¿Qué tipo de cine se acerca más a esta idea? Y este cine de imagen-tiempo, ¿se puede conectar a la lógica narrativa o más bien a otro tipo de discurso, hablando en términos de diálogo entre las artes, es decir, de intermedialidad?

A partir de esta pregunta, ponemos el foco en un adjetivo que muchos críticos utilizan a la hora de analizar esas películas, que resultan ser diferentes en el sentido apuntado: el cine poético ${ }^{2}$. ¿A qué se refieren con este concepto? La hipótesis de este trabajo recae en esta cuestión, es decir, en la

no mantiene una relación de dependencia causal con ninguna otra imagen anterior o posterior. En la solidez de este aspecto reside la similitud que se puede buscar también dentro de la subjetividad del punto de vista de la cámara en el filme y del verso en el poema: hemos dicho que son los personajes los que definen el tiempo de la película, así como es la voz del verso la que define el tiempo del poema.

2. En el cine poético, reconocemos la poeticidad por el hecho de que el argumento se subordina a los requisitos del «verso», es decir, de las técnicas utilizadas por el cine para que también estos elementos participen de la temática de la película misma. Los colores, las luces, los encuadres también son reconocidos como elementos determinantes de la historia de la película, porque ellos también contribuyen a «escribir» el argumento. Este cine puede ser definido también como paramétrico, definición elaborada por Noel Burch y reconsiderada por David BorDwell (1996), quien se refiere a la posibilidad de un cine que se opone a la narrativa de tipo clásico por el hecho de estar más centrado en el estilo que en el argumento o, mejor dicho, por lograr que el estilo fílmico sea parte integrante de la misma historia. Pier Paolo Pasolini también utilizará este mismo concepto de cine poético en sus películas. 
posibilidad de considerar un tipo de cine que no sea única y fundamentalmente "narrativo", sino que esté más cerca de la poesía que de la linealidad narrativa. Este concepto de cine se encuentra también en los orígenes del cinematógrafo, donde: «El peso de la palabra impresa coexiste con la palabra transmitida en el medio filmográfico", como afirma Víctor Amar (2003, 433). Lo que se quiere transmitir a través de esta afirmación es que, cuando nació el cinematógrafo, todo lo que se enseñaba en la pantalla se acompañaba de la presencia de diálogos subtitulados o personas que leían en voz alta lo que aparecía en esa pantalla. Es decir, que todo lo que el cine mostraba a los espectadores en principio era esencialmente imagen y palabra escrita. Sin embargo, Amar intenta también considerar algunos elementos del cine que actúan de la misma forma que en la poesía, que son partes imprescindibles del lenguaje cinematográfico y que encontramos, precisamente, en la poesía misma, aunque de forma distinta. Amar insiste en el hecho de que ambas artes, poesía y cine, se centran en la percepción del placer y en la estimulación de los sentidos, porque sugieren y comunican a la vez, prolongando la imaginación de los receptores. Además, ambas artes se consideran complementarias y correspondientes, ya que, como afirma Amar, en un sentido teórico metafórico, en un verso se podría ver un primer plano, así como en un primer plano lo mejor de los versos de un poema (Amar 2003, 434). Un punto importante en el que se subraya la relación entre estas dos artes es también la complementariedad de los elementos: las dos artes, según Amar, son ritmo y montaje, fragmentación y velocidad, metáfora y estética, aparte de ser ambas la expresión máxima de la representación de la belleza y del deleite (Amar 2003, 436).

Las relaciones cine-poesía forman parte de este complejo y rico entramado de relaciones de intermedialidad, que realmente hunden sus raíces históricas en la tradición clásica y moderna de la máxima horaciana ut pictura poiesis o de "las artes hermanas". La perspectiva de esta tesis ubica estas relaciones en el terreno más amplio de las conexiones palabra-imagen, siempre dentro del ámbito de la literatura comparada y de sus últimos planteamientos en torno a esta tradición de estudios interartísticos.

\section{NOCHES BLANCAS, EJEMPLO DE CINE POÉTICO}

Para ilustrar esta reflexión, tomaremos como ejemplo una película que contiene en su estructura muchos de los rasgos que consideramos poéticos y que nos ocuparemos de desarrollar a lo largo de este trabajo: Noches Blancas (1957), la adaptación cinematográfica realizada por Luchino Visconti de una novela del 1848, escrita por Fedor Dostoyevski en su época juvenil. 


\subsection{La reescritura viscontiniana del texto de Dostoievski}

En el fondo de un San Petersburgo casi desierto, silencioso y ausente, el protagonista, en su incomunicabilidad, vaga en plena soledad por las calles de la ciudad en verano, cuando todos los habitantes se han despedido de ella para irse de vacaciones. La película, sin embargo, se localiza en Livorno, Italia, donde el protagonista es Mario, interpretado por Marcello Mastroianni, un hombre completamente abandonado a sí mismo, que no entabla ningún tipo de diálogo con nadie y que nunca ha conseguido establecer una relación normal con sus semejantes: solo las casas y las calles de su ciudad parecen interesarle, solo con ellas consigue instaurar una increíble empatía. La ciudad vacía exaspera aún más la imagen de este aislamiento psicológico en el que vive y que delinea su figura misteriosa. La vida de este hombre está completamente aislada de la realidad de su entorno, dirigiéndose, en cambio, hacia los sueños y las ilusiones que lo nutren. Su vida se alimenta de estas ilusiones, del engaño de las noches y disfruta de esta imaginación, ignorando a las personas que viven demasiado ligadas a la realidad.

De improviso, durante una noche perdido en sus pensamientos, conoce a Natalia (en la novela Nasten'ka), que se convierte en la única persona con la que consigue expresar sus pensamientos y liberarse de sus inquietudes interiores. Natalia, interpretada por Maria Schell, es una mujer decepcionada por un hombre, al que espera cada noche en un puente para que se cumplan sus deseos amorosos. La espera se convierte en el instrumento que permite el acercamiento entre los dos personajes, que representan a esos "observadores» de los que hablaba Gilles Deleuze ${ }^{3}$. Podemos considerar, de hecho, el encuentro entre los dos protagonistas como el comienzo de una profunda reflexión sobre la humanidad y la búsqueda de la realización sentimental. Mario y Natalia pasean por las calles desiertas su desolación y su decepción respectivas. El vacío que sienten alrededor de sus cuerpos, en el paisaje blanco y nevado, representa la imposibilidad del cambio, donde todo se permanece helado, como parado e inerme. Este aspecto, que Visconti extrae de la novela y que resalta visualmente en su película, es la condición de los personajes que se sienten imposibilitados

3. Deleuze habla del Neorrealismo como un "cine de videntes», donde los personajes no son víctimas de las acciones, sino que se ven de improviso sorprendidos por la realidad, sobre la cual reflexionan y construyen pensamientos (Deleuze 1987: 13). Trataremos de ahondar en esta afirmación para demostrar que esta característica, que liga la imagen fílmica al tiempo y no tanto al movimiento de las acciones que se suceden en ella, puede considerarse un rasgo poético de una cierta relevancia. 
para la acción y permanecen absolutamente paralizados limitándose a ser meros observadores de lo que les ocurre. Este es el concepto que Deleuze ha desarrollado plenamente referido a un cine cuyos protagonistas, aunque se encuentren en un entorno bien definido y muy cercano a la realidad, observan los acontecimientos y sacan sus conclusiones respecto a lo que ocurre, pero sin participar activamente. Lo que hacen los personajes es construir su propio pensamiento sobre la base de ese entorno: Natalia y Mario, dentro del aislamiento, reflexionan sobre esa realidad abandonada y silenciosa.

En los momentos que pasan juntos durante las noches donde se cuentan sus deseos y sus sueños, la una se convierte en la ilusión del otro, intercambiando instantes de sonrisas y lágrimas, observando la realidad y observándose a sí mismos: son uno el espejo del otro. Luchino Visconti condensa el tiempo de los personajes dentro de las imágenes, comprimiendo el pasado y el futuro, presentándonos una situación de eterno presente, estático, resaltado también por el ambiente que los rodea en el que los protagonistas se quedan como bloqueados, incapaces de superar sus crisis y sus tragedias personales. Deleuze afirma que «el cineasta debe alcanzar lo que el personaje era "antes" y lo que será "después", debe reunir el antes y el después en un tránsito incesante de un estado al otro» (Deleuze 1987, 206). La imagen-tiempo descrita por Deleuze es la imagen cinematográfica cuyo tiempo es comprimido en un eterno presente, donde los personajes observan su vida incesantemente, sin poder actuar sobre la realidad, sino reflexionando sobre ella, mostrando sus pensamientos y sus miedos.

Sin embargo, Mario y Natalia parecen moverse en un espacio muy lejano de la realidad a la que pertenecen porque sus movimientos se realizan dentro de la oscuridad nocturna, como si estuvieran andando por un mundo más cercano al de los sueños, por donde pasean casi de forma circular, recorriendo unos pocos lugares (el puente de su encuentro, el bar...) a los que vuelven reiteradamente. Este continuo retorno al mismo lugar da la impresión de una imposibilidad de avance y desarrollo de las acciones, porque los personajes se encuentran atrapados dentro sus propias inquietudes, que pertenecen a un presente inamovible. De hecho, veremos que, cuando al final Natalia encuentra a su amado, en el encuadre, filmado en plano americano, ella se queda junto a aquel en una posición adelantada, como si hubiera conseguido romper y resolver una situación en la que se hallaba atrapada y ahora es capaz de avanzar; en cambio, Mario permanece atrás, en segundo plano, como bloqueado en un presente estancado del que no consigue liberarse. Además, la última escena lo muestra solo, pasando de nuevo por el lugar donde antes había creído poder conquistar el corazón de Natalia y donde ahora se queda desilusionado y resignado a su destino. 
En Noches Blancas encontramos el tema del "Soñador», tanto en la novela como en la película. Este importante elemento ideológico del sueño, mágico y real al mismo tiempo, es el núcleo sobre el que se desarrolla la historia. Sueño y realidad; tiempo y espacio: estos son los elementos principales a analizar. De hecho, Dostoievski sitúa la historia en un San Petersburgo vacío, en una época de vacaciones, cuando la gente se escapa de la ciudad para respirar la libertad del verano, ganada después de un crudo invierno. El título Noches Blancas hace alusión a un período del año particular del norte de Rusia cuando el sol se pone después de las diez de la noche. Entonces estas noches de las que habla Dostoievskij son verdaderamente blancas y luminosas, casi como el día. La presencia de la noche en la película responde fielmente a la novela: en ambas el espacio nocturno donde deambula la pareja tiene una dimensión onírica, subrayada a lo largo de todo el metraje.

Se percibe una total ausencia de lo que ocurre alrededor de los dos jóvenes, como si ese entorno estuviera apagado o perteneciese al ámbito del sueño. El protagonista recuerda, narra, olvida mezclando todas sus imágenes con recuerdos fotográficos de la ciudad, llegando a un punto en que el espacio y el tiempo se confunden en un único gran complejo que no sabemos si es real o no. Este aspecto está subrayado en la novela donde, en las descripciones del ambiente, existe una continua referencia a la alternancia de luz y oscuridad que demuestra la continua transición entre el estado onírico en que se mueve la mente del protagonista y la realidad de la vida normal desde el momento en el que encuentra a Nasten'ka. Este aspecto es menos evidente en la película, porque también las escenas donde aparece Natalia sugieren un ambiente onírico, aunque más despejado: es como si la protagonista femenina representara una pequeña posibilidad de iluminación para Mario. De hecho, el nombre Nasten'ka, es el diminutivo de Anastasia, que significa literalmente «despertar» o "resurrección». Este detalle es muy significativo, porque confirma el momento crucial en el que el protagonista se da cuenta de que quizás exista una realidad, un llanto, una expresión de tristeza y rabia, algo real, una vida que se puede tocar, oler, degustar y ver. Visconti retoma este detalle poniendo a la protagonista el nombre de Natalia, que remite a la idea de "renacimiento". La diferencia sustancial es que en la película se evidencia el «aspecto soñador» más en el personaje de Natalia que en el de Mario, quien tiene miedo de separarse y de ir más allá del entorno en el que se desenvuelve su vida.

El concepto de tiempo comprimido en un eterno presente, tanto en la novela como en el filme, se presenta como una mezcla de épocas, momentos, circunstancias particulares que se desarrollan a través del pensamiento de los protagonistas y que no sabemos si son verdaderos o si son el fruto 
de su imaginación. Las digresiones sobre la vida y los problemas descubren el mundo interior de los personajes y nos acercan a su subjetividad, dejando siempre clara su intención de quedarse al margen de los eventos, como observadores. El sentido del eterno presente viene marcado también por la falta de una dimensión espacio-temporal precisa porque, como ya hemos dicho antes, Dostoievski no identifica una época clara: todo puede pertenecer a cualquier dimensión temporal, un tiempo que es del alma, de dos criaturas que se encuentran emergiendo desde el espacio interior de sus respectivos espíritus para proyectar adelante sus inciertos futuros.

Por esa condición en la que se desarrolla la relación entre la pareja, el tiempo real se confunde con el tiempo del sueño efímero, con el momento del encuentro entre ambos, sin que percibamos el transcurso de los instantes, si van hacia adelante o hacia atrás: todo es presente. Eso se refleja también en las formas gramaticales utilizadas en la novela: el presente es el tiempo del discurso, de los diálogos y del amor y lo mismo en la película.

Notamos que casi nunca hay referencias al pasado o a un posible futuro en los diálogos entre los protagonistas. Todo ocurre en pocos momentos: los sentimientos, los diálogos remiten a una unicidad, a una singularidad temporal y espacial que forma parte del sentido más importante de esta historia: el encuentro con el otro, que comporta el conocimiento de sí mismo y del entorno real. Los espacios más recónditos del alma, los de los sueños, de las ilusiones, de las dudas miserables que se comparten con el "otro". Este juego continuo en Noches blancas es una mecánica espacio-temporal que se reconduce al tema del «espejo»: él se "mira» en ella y al revés, ambos intentan entrar en el otro, en las historias que se cuentan.

Es justamente con este mecanismo con el que Visconti construye a sus protagonistas: a uno le hace falta la otra y viceversa, en un juego de intercambios lingüísticos, de movimientos, de miradas. Hemos visto, entonces, que el espacio y el tiempo son dos aspectos poco definidos y bastante aleatorios que se resuelven en el concepto de un presente perenne e incumplido. Está claro que la idea de un encuentro sin tiempo da a la obra una cierta universalidad: el encuentro entre los jóvenes es el símbolo de una importante verdad humana, la precariedad de la vida con todas sus dificultades, y lo que queda es solo «Un momento de beatitud... ¿Quizás sea poco en toda la vida de un hombre?» (Dostoievski 2007, 102). Esta frase con la que termina la novela es retomada al término de la película en el monólogo final de Mario, que irrumpe con fuerza e intensidad, cerrando definitivamente la narración fílmica.

El concepto de "cine de vidente» deleuziano se encuentra también en el sistema discursivo y psicológico de la historia, que presenta una continua revelación y un continuo cambio de posición, un intercambio de las partes 
que se revela poco a poco en el pesimista final del que hemos hablado antes: todo es ilusión, la vida es un momento que tiene que ser disfrutado en cuanto tal. Otra vez, el tiempo comprimido se revela como el espacio en el que los personajes se observan y cambian continuamente, no porque haya alguna acción que les obligue a cambiar, sino porque son sus observaciones, pensamientos y reflexiones los que les cambian.

Un hombre y una mujer que se encuentran en el espacio más secreto de sus sueños; una mezcla de alegría y nostalgia, subrayada por un ambiente casi siniestro, oscuro; calles de una ciudad que duerme casi todo el tiempo de la película; juegos de claroscuros y paisajes nevados: esta es la escenografía casi pictórica que envuelve a los personajes de Visconti y los convierte en símbolos de la humanidad entera.

\subsection{La propuesta formal de Visconti}

Centrándonos en la realización de la película, observamos cómo todo el entorno refleja la interioridad de Mario, un intelectual pobre, en los márgenes de la sociedad, empleado en una actividad que parece no tener sentido en su vida, sumergido en el vacío de sus contradicciones artificiales. Por otro lado, Natalia, la mujer que, con su aspecto débil y algo ingenuo, se convierte en su objetivo de mejora, en su esperanza de amor, la de un hombre que en la película no tiene que superar su soledad como en la novela, sino su mediocridad. Los sentimientos de los personajes se transfieren al entorno escenográfico, deliberadamente teatral, subrayando una artificiosidad que aleja a la película de la vocación naturalista del cine clásico y le proporciona una cierta dimensión poética. Observamos cómo los personajes se ven sorprendidos por esta realidad circundante sobre la cual reflexionan y construyen pensamientos sin sentir el peso de las acciones. Esta condición, conectada con el tiempo, confiere a todo el filme un significativo carácter poético, que hemos mencionado también anteriormente, refiriéndonos a la teoría deleuziana de la imagen-tiempo.

Visconti ha optado por llevar a cabo la filmación de la película en un espacio recreado en estudio. Ello se debe a tres motivos principales:

- El primero se relaciona con la huella estilística que ha querido imprimir a la película conectándola con la naturaleza de la historia, la cual al transcurrir en un espacio a caballo entre la realidad y la ficción, no admitía, por tanto, un tratamiento naturalista.

- El segundo era evitar problemas de orden técnico como los derivados de las condiciones atmosféricas, que podrían ser adversas. 
- El tercero se explica por su concepción de la película como una reacción a las fórmulas neorrealistas, lo que le lleva a rechazar la posibilidad de filmar directamente sobre espacios naturales, como era habitual en los cineastas de aquel movimiento.

Esta última razón alude al propósito de recrear una realidad ajena a toda intención documentalista y que respondiese a la percepción subjetiva de los personajes. De hecho, la puesta en escena se lleva a cabo en un doble escenario en el que conviven la parte vieja y la parte nueva de la ciudad para dar al espectador la idea de contraposición de los estados de ánimo que viven los protagonistas, los cuales pasan de momentos de felicidad y alegría inmensa a instantes de melancolía, tristeza y enajenación. Remitimos a este respecto a la afirmación de Jenaro Talens (2010: 60-65 $)^{4}$ sobre la imagen que significa más de lo que parece ya que la focalización desde el punto de vista de los personajes introduce un componente de subjetividad que proporciona un indudable sentido poético a toda la película.

Por ejemplo, es significativa es la escena en la que Mario lleva a Natalia a un local donde, mientras están tomando algo de beber, la gente empieza a bailar delante de ellos de una manera tan sensual y explícita que contrasta con la actitud de los protagonistas; estos parecen encontrarse incómodos por lo que está pasando y, sin embargo, con ganas de intentar hacerlo ellos también. Visconti utiliza este recurso para subrayar que los dos jóvenes no se dejan llevar por las emociones y, aunque parezcan sentir ganas de explorar sus deseos de dejarse mecer por esta música tan atractiva, los reprimen. Resulta interesante el juego plano-contraplano utilizado en esta secuencia por el director, alternando el encuadre de los personajes tímidos y casi torpes con el de los bailarines que se entregan a un baile extravagante y provocativo. Mediante este recurso se muestran al espectador las dificultades de los personajes, sobre todo de Natalia, de adentrarse en el mundo de las sensaciones, que le parece siempre demasiado lejano e inaccesible. De ese modo se expresa la continua mutabilidad de la actitud de los protagonistas, quienes cambian en función de lo que piensan y no por lo que sucede.

La luz también posee en la película unas características muy significativas. Durante los diálogos entre la pareja, una luz muy fuerte subraya sus

4. Jenaro Talens propone una forma diferente de concebir el filme en una nueva relación con el espectador a quien la imagen le sugiere un significado que él poco a poco va construyendo. Hablamos aquí de la «mirada constructora» 
sonrisas; es magistral a ese respecto es la escena final, cuando Mario parece lograr el amor de Natalia, quien permanece entre sus brazos, seducida por las palabras tranquilizadoras de él. La iluminación aparece difusa, compensada, evitando los contrastes y creando un ambiente de tranquilidad. De repente, aparece una pequeña sombra en sus rostros, como si fuera una señal, como algo que mitiga la luz que los estaba iluminando y el espectador se da cuenta de que algo va a pasar a continuación. En un siguiente encuadre, que parece casi mágico, se muestra a ambos abrazados en un barco, asombrados ante la visión de la nieve; y, mientras permanecen en esa posición serena, el barco, en primer plano, se mueve acunado por el mar, como si anunciara un posible cambio, una repentina intrusión en esta aparente tranquilidad. La luz, de hecho, se utiliza como un recurso poético en el sentido más técnico del término: permite el cambio de una escena a otra o una repentina mutación en la misma escena, como una figura retórica que en un poema "colorea" los versos, dándoles un aspecto novedoso.

La nieve también, en este caso, no es solo un decorado, sino mucho más: representa un elemento casi sobrenatural que cae desde el cielo para ilusionar a los personajes y lograr una tranquilizadora apariencia de quietud. El paisaje recuerda las pinturas de Friederich, con sus tormentosas visiones de panoramas naturales relajantes y, a la vez, inquietantes. Árboles nevados, sonrisas y miradas hacia el cielo, como si esta nieve marcase el logro final de todos los sueños esperados. La nieve representa también la "Congelación" de los protagonistas, la imposibilidad de avance de la que hemos hablado anteriormente, el bloqueo. Cuando Deleuze afirma «es preciso que la imagen abarque el antes y el después» (Deleuze 1987, 208), está refiriéndose al tercer tipo de imagen-tiempo, que reúne pasado y futuro en un continuo devenir. La nieve es, en este caso, no solo la revelación que los personajes estaban esperando, el símbolo de un pasado (helado en la mente) y un presente (bloqueado) que se convierte en el futuro tan esperado, sino que, al mismo tiempo, es también la "manta» estática que cubre a ambos para mantenerlos aislados en el momento presente, lo que está relacionado con el concepto de imagen-tiempo como simultaneidad de acciones: mientras la nieve está dejando de caer, simultáneamente, aparece un hombre en el puente que resulta ser el amado de Natalia, tan esperado. Así, el último instante de alegría termina al cesar la nevada y mientras que los personajes caminan por los callejones de la ciudad, Visconti nos ofrece una sugestiva escena utilizando la profundidad de campo, a través de la cual percibimos, solo en un segundo momento, la presencia de un hombre, completamente en sombra, a lo lejos.

Aquí también tenemos un tiempo condensado en el que el presente, lo recién pasado y el futuro se superponen en el mismo encuadre, para 
que los personajes observen ("cine de vidente») toda la realidad que tienen delante y tomen sus propias decisiones. La perspectiva cambia: ahora la cámara ya no sigue a los dos jóvenes, sino que se sitúa en el otro lado, junto al puente donde se encuentra esta figura, que parece misteriosa, tapada por un abrigo y con una cara muy poco definida. Entonces el espectador empieza a entender que este hombre misterioso representa el final de una historia que termina al dejar de caer la nieve. Así vemos a Natalia correr hacia él y de repente un plano medio encuadra a los dos amantes mientras Mario permanece detrás, pequeño y solitario, en medio de la imagen; entre él y la pareja se extiende un puente que cruza la calle, como si quisiera mostrar al espectador que entre la realidad y el sueño hay vías tortuosas, subidas y bajadas difíciles. Con ello, Visconti está aludiendo metafóricamente a una posibilidad de salida de esa realidad en la que los personajes se encuentran permanentemente atrapados a la vez que expresa la precariedad de una vida compuesta de momentos distintos y con un futuro incierto. Es una escena que puede resumir los significados más profundos de la historia: edificios decadentes, puentes de paso, colores gélidos de un invierno interior. Todo ello en una composición casi triangular, donde el protagonista, como ya hemos apuntado anteriormente, permanece en la parte alta del encuadre como si fuera un Dios decepcionado por sus criaturas, que al final se muestran mucho más reales de lo que él había imaginado o sentido, retomando la imagen con que el mismo Dostoievski los había descrito y que Visconti reinterpreta a su manera.

Es preciso recordar, igualmente, la escena en la que Mario, dándose cuenta de que no puede lograr el amor de Natalia (quien además no se presenta a la cita), encuentra a una prostituta que intenta insistentemente seducirlo. El personaje de la prostituta, introducido por Visconti ex-novo, remite a una realidad más concreta y más dura, en el polo opuesto a lo que evoca la figura de Natalia. La prostituta es la otra cara de la ciudad, representa su lado oscuro y sórdido, del que Mario quiere huir. Pese a los continuos intentos por parte de la mujer de distraer a Mario de sus sueños y de devolverlo a la realidad, él casi todo el tiempo le habla dándole la espalda, sin mirarla, como si quisiera evitarla y escaparse de esta realidad tan brutal. El contraste luminoso proporciona a la escena un halo casi místico, ilusorio. El rostro de Mario, iluminado solo lateralmente para que la luz subraye en un único lado dejando el otro en sombras, refuerza la sensación de una personalidad inquieta, desdoblada, confusa. La habilidad de Visconti reside en dejar hablar solo a las imágenes con la iluminación, con la expresividad de los personajes y con las sugestiones del mundo la circundante. 


\subsection{Una nueva concepción del realismo}

Como ya se ha dicho antes, Visconti intenta en Noches blancas, en cierto modo, alejarse de la estética neorrealista que hasta entonces había cultivado, intentando acercarse a un mundo más poetizado, más irreal y próximo al de los sueños. Frente a sus anteriores películas, Noches Blancas se aleja de toda intención documentalista para abordar una realidad revelada a través de la mirada de los personajes. Cabría hablar, entonces, de un realismo "inventado", de una realidad subjetiva que constituye también una parte de nuestras experiencias.

Sobre la noción de "realismo", Santos Zunzunegui recuerda que el debate en torno a la misma «da cuenta de una idea bien sencilla: el hecho de que cualquier obra de arte remite, de una u otra forma, a la realidad a la que pretende (a veces incluso de manera negativa) referirse» (Zunzunegui 2002, 472). Esta definición de realismo, según el autor, «prescinde de un significado ecléctico ya que algo que sea "real" hay que especificarlo, diferenciarlo en cada caso y en la práctica» (Zunzunegui 2002, 473), así que no podemos definir de por sí un concepto estándar de realismo. Visconti, liberándose de las premisas neorrealistas, nos propone una reformulación de la realidad filtrada a través de la conciencia de los personajes.

Jenaro Talens propone una dicotomía entre la realidad y lo real que explica del siguiente modo:

[...] Lo que conocemos como «realidad» es impensable fuera de los dispositivos que nos permiten pensar, es decir fuera de su formulación verbal; sin embargo hay cosas que sentimos y experienciamos [...] antes de saber cómo verbalizarlas [...] No digo que esas cosas no sean lenguaje, sino que no son lenguaje verbal, y esa distinción, semióticamente hablando, es importante (Talens 2002, 97-98).

Según Talens no es la misma experiencia, por ejemplo, sentir la «maternidad" $\mathrm{O}$ "paternidad" en una cultura cuyo lenguaje no tenga el pronombre "yo", así que lo "real" posee un sentido psicoanalítico, "como aquello que no tiene acceso al lenguaje, y que, por tanto, no se puede nombrar» (Talens 2002, 98). Así pues, al hablar del realismo de Noches blancas, no nos referimos a una realidad con pretensiones de objetivismo documentalista sino a una nueva experiencia de realidad construida e inventada.

\subsection{La dimensión poética del filme}

Pasemos ahora a considerar los procedimientos mediantes los que Visconti se ha acercado poéticamente a la historia narrada por Dostoievski. 
Si apelamos a la categoría deleuziana de la imagen-tiempo, podemos considerar que Visconti crea en el filme un tiempo comprimido entendido como un presente continuo que captura a los personajes y al espectador. Esa presencia continua de un tiempo en presente es la más cercana al acto poético, independiente de cualquier tipo de causalidad temporal propia de las narraciones convencionales. Para Deleuze la imagen-tiempo remite no un a una realidad ya descifrada, sino a una realidad "a descifrar, siempre ambigua" (Deleuze 1987, 1), sometida al punto de vista subjetivo de los personajes. Su concepto de "cine vidente», implica el que, a través de algunas interrupciones de acciones cotidianas debidas a accidentes o simplemente a "visiones» por parte de los personajes, surge una situación que es óptica, es decir, que nos permite ver algo y percibir directamente el pensamiento. La visión vale por sí misma, sin necesidad de recurrir a la racionalidad. Así las imágenes adquieren una dimensión atemporal, siempre presente, eterna y viva como la poesía.

El concepto de poesía no se opone, pues, al de narración, porque lo poético también puede ser narrativo. Se trata, más bien, de identificar una forma de narración distinta, que no esté ligada a ningún tipo de causalidad y que rescate la idea de asociación de las imágenes más conectada subjetividad de la mirada que a la causalidad de los eventos en los que está involucrado el personaje. Esto puede provocar que la imagen adquiera una carga estética bastante importante, porque el ojo del espectador se concentra más bien en la forma en la que está construida la imagen en la escena y en la mirada de los personajes. Esta subjetividad también es un elemento que tenemos que considerar como poético. Como hemos definido anteriormente, la poesía posee una carga de subjetividad vinculada al campo semántico al que se refiere. Ello es debido al hecho de que la forma poética se revela ya de por sí, por su esencia, como estilo. Lo contrario de lo que ocurre en la prosa, donde la frase de un párrafo o de un capítulo es percibida antes por su significado que por sus cualidades estéticas.

David Bordwell (1996), como anotamos más atrás, considera la existencia de cuatro tipos de cine, entre los cuales se encuentra el llamado "cine paramétrico", donde el nivel estilístico prevalece sobre el argumental. De acuerdo con ello, Noches blancas podría calificarse como cine paramétrico y, por consiguiente, poético. Para demostrarlo, consideremos el ejemplo concreto de la última escena en donde la composición visual prevalece netamente sobre lo argumental, es decir, que es el mismo estilo el que habla y nos cuenta lo que está ocurriendo. La disposición triangular de dicha escena, permite, como hemos anticipado, ver a Natalia y a su amante en un primer plano americano y a Mario en el fondo, separado de ellos por un puente: esta triangularidad enfatiza la tensión existente entre los 
personajes. El significado está dentro de la composición, que podemos calificar como pictórica, de la escena: todo está absolutamente delineado por los claroscuros del blanco y negro cuya luz resalta a los personajes que se encuentran delante, destacando sus figuras; las líneas curvas del puente y del trayecto indican un camino difícil hacia la consecución de un amor, es decir, la propia meta. Todos estos recursos estéticos son utilizados por Visconti para elaborar un tipo de película alejada del cine clásico, de línea argumental causal. Aquí todo se resuelve dentro de una sola imagen, sin necesidad de esperar a que aparezca la sucesiva ni a que se cumpla una acción, porque la acción misma está subordinada al estilo de la escena y esta esteticidad provoca un profundo éxtasis de los sentidos, más allá de la comprensión intelectual. Este protagonismo de los elementos expresivos que encontramos dentro de Noches blancas es un elemento determinante para nuestra consideración de cine lírico.

Más allá del concepto de imagen-tiempo y de cine paramétrico, en Noches Blancas observamos también una perfecta correspondencia entre imagen y palabra, acercando en este caso la literatura en prosa a las imágenes, como si fueran pinturas, es decir, emparentando la palabra con las artes visuales. Esta película es un claro ejemplo de intermedialidad, del conjunto de relaciones entre los medios artísticos, porque, a pesar de las disonancias entre los diálogos de los personajes y las imágenes que se nos ofrecen, no existe discontinuidad entre ambos lenguajes, sino, al contrario, una continua retroalimentación. La verdadera cuestión está en entender cuáles son las diferencias que aporta esta película con respecto a otras adaptaciones más tradicionales de textos literarios: la novedad es, desde nuestro punto de vista, precisamente lo que la convierte en poesía.

¿En qué sentido? Lo poético en Noches blancas ha de buscarse en lo sugerido, en la realidad que el espectador ha de descifrar para darle un significado propio. El espectador busca continuamente sentidos en las imágenes que ve y en la historia que se desarrolla delante de sus ojos.

Noches Blancas es la metáfora de la humanidad en perenne búsqueda de la felicidad, de una luz en mitad de la noche, de un sueño en la dura realidad. La metáfora de una humanidad entera a través de estas imágenes que parecen espléndidos cuadros en blanco y negro, que se mueven en la pantalla. Y de la misma forma que estos "cuadros» muestran, a través de la imagen, un objeto o mediante un elemento temático, una metáfora de algo distinto, que produce correspondencias inesperadas, así actúa la poesía a través de las palabras. Sin embargo, son estas mismas palabras las que nos hacen imaginar lo que se nos cuenta desde la pantalla mediante las imágenes. Como afirma Lotman en su Diálogo con la pantalla y como vimos ya, esta es "la verdadera esencia del cine mismo, el "Gran mudo", es decir, no 
un taciturno, no el que habla por hablar, sino el que desea ser entendido, que se expresa con los gestos y con la mímica, con su misma mudez. El cinematógrafo habla y desea ser entendido» (Lotman 2001, 10). Y así habla la poesía de Visconti en esta película, con sus extraordinarios matices y pinceladas pictóricas, donde el estatismo de la imagen, el relieve de cuerpos y objetos conseguido con la iluminación y la intensidad simbólica de los planos hacen que sus planos semejen pinturas. Esta relación de la película de Visconti con la pintura, se manifiesta también en el hecho de que el director se inspirase en algunos cuadros famosos para organizar la disposición de los personajes o de los objetos en el encuadre.

Para terminar, hay otro aspecto que sería interesante considerar respecto a la relación entre este cine superador del neorrealismo y la poesía. Es un cine muy vinculado al realismo poético francés, que a través de la utilización subjetiva de la cámara muestra lo que el personaje ve desde su punto de vista y también los sentimientos que está experimentando. Esta visión más psicológica y subjetiva de la realidad es decisiva en la Nouvelle Vague francesa, una corriente cinematográfica que intenta capturar el esplendor de lo real y verdadero, y de la que hemos hablado con anterioridad. En sus películas no hay nada artificial que se interponga entre la realidad y están rodadas con medios improvisados.

Pier Paolo Pasolini, como se ha dicho anteriormente, uno de los más importantes intelectuales del siglo XX en Italia, afirma que la poesía da la esperanza de poder decir todo, más aún que la literatura en prosa, porque emerge de una voluntad interior extremadamente irracional y también representa un trámite entre el yo y la crisis social en la que vive el autor. La sublimación de la crisis ocurre a través de las imágenes que pueden ser universales y comunicativas. La poesía es síntesis. La imagen es síntesis. De esto deriva que la imagen es poesía (Pasolini, 1970).

De esta manera, se puede afirmar que existe un cierto tipo de cine que comunica a través de las imágenes más que con la historia, transformándose en poesía y esto es lo que sucede en el caso de Noches blancas y de otras películas que se apartan de los presupuestos neorrealistas La imagen, extendida en sentido poético, comunica más de lo que aparentemente significa, como también ha explicado Jenaro Talens en El ojo tachado, a propósito de Buñuel:

Cegando, tachando, el ojo del espectador y sustituyéndolo por el ojo (invisible) del objetivo de la cámara, un film no sólo decide qué podemos ver, sino en qué momento y desde dónde. El discurso fílmico jamás reproduce la realidad, sino la (re)produce como interpretación de alguien que se inscribe en la forma de montaje» (Talens 2010, 89). 
Podemos aducir también la opinión de Antonio Monegal, quien, en su En los limites de la diferencia, afirma:

El discurso sobre las relaciones entre palabra e imagen puede ser leído como un discurso sobre la corriente cinematográfica que se desarrolla en Francia en los años '30, sentando las bases para el cine moderno. Una de sus características es la manipulación subjetiva de los encuadres, mostrando no solo lo que el personaje ve, sino también lo que siente. Entre los exponentes más significativos recordamos a Jean Epstein, Jean Vigo y Jean Renoir. La relación entre el signo (palabra o imagen) presente y lo otro, la cosa, que está necesariamente ausente en el signo para que se cumpla como tal (Monegal 1993, 32).

Evidentemente, "la cosa» representa el objeto de la realidad al que la imagen remite. Teniendo en cuenta que la diferencia es la manera de representar esta "cosa", Monegal, como ya hemos visto antes, tomando en consideración el concepto de ut pictura poiesis, define la poesía no solo y exclusivamente como un arte verbal, sino como «un rasgo potencialmente presente en cualquier actividad artística, con independencia del medio" (Monegal 1993, 34). La poesía adquiere un significado más extenso y se convierte en una característica o un adjetivo extensible a otras formas artísticas.

Retomando el concepto de cine de poesía de Pier Paolo Pasolini, podemos notar en el posneorrealismo italiano una representación de la realidad a través de la subjetividad marcada por el director, que concentra la cámara en los sentimientos y en las sensaciones de los personajes que viven la cotidianidad tal y como es. La prosa, como la veía Rohmer, director y crítico cinematográfico suizo, puede ser transformada en una película, asumiendo la forma de una pantalla, pero le falta la síntesis: esta tiene su máxima expresión en la poesía (Rohmer, 1970). En este cine, que es justamente una nueva representación de la realidad, encontramos la perfecta armonía entre la realidad exterior y los sentimientos escondidos de los personajes. Esta misma poesía está plasmada en Visconti, en sus escenas, en sus paisajes y en sus personajes que son tipos universales, que van más allá de la dimensión temporal para convertirse en inmortales como, de hecho, sucede en la poesía.

\section{CONClusiones}

Después de haber analizado Noches blancas, pasemos a resumir cuáles son los elementos que hemos tenido en cuenta para definir su poeticidad. 
La teoría de la "mirada constructora" es una de las claves de nuestro trabajo en el que también hemos tenido en cuenta el concepto de «espacio textual»(Talens, 2010).

Noches blancas está escrita y realizada, no para representar un correlato referencial o comunicar un significado previo establecido (además de modo narrativo), sino para generar un espacio de posibilidades de sentido que el lector-espectador debe construir y concretar. De hecho, consideramos la película poética como un espacio único donde los espectadores construyen su propio sentido, que no alude a ninguna anécdota narrativa, pues "cada elemento remitiría operacionalmente a otros elementos dentro de la inmanencia del sistema cerrado que construye el espacio textual» (Talens 2010, 63). Talens hace una distinción con el discurso narrativo, donde "la articulación de los acontecimientos se establece respecto a una lógica que la vuelve verosímil. Dicha verosimilitud se basa en un desplazamiento de lo temporal hacia lo causal» al contrario que el discurso poético, donde, "la articulación, no sometida a acontecimientos, es azarosa, en el sentido en que no constituye un universo cerrado en sí mismo sino una sucesión de fragmentos» (2010: 65). Con "cerrado» aquí Talens se refiere al hecho de que en un discurso narrativo un acontecimiento provoca otro acontecimiento en un mecanismo que podemos definir como causal y oclusivo, mientras que un discurso poético está "abierto" a diferentes posibilidades de significado y obliga a un proceso de re-creación y re-construcción del sentido por parte del receptor (hablamos, claro está, de los procedimientos más comunes en la prosa narrativa, lo cual no significa que dejemos de contemplar la posibilidad de otras formas narrativas más experimentales o vanguardistas que, de hecho, generan relatos abiertos y no sometidos a la lógica causa-efecto).

Así que los receptores, en un cine de poesía, participan de y construyen el significado de la película, conectando los fragmentos dentro del espacio textual fílmico, que es el único lugar donde se realiza el sentido del filme y donde no solo las "presencias" adquieren un significado, sino también las «ausencias« (lo sugerido, lo que no aparece, lo invisible). Estas últimas constituyen la clave para mirar un filme.

Otra reflexión esencial a lo largo de nuestro trabajo, citando de nuevo a Víctor Amar, es la que atiende, no solo al disfrute o deleite inscrito en el acto de lectura del texto fílmico (concepto conectado claramente con la jouissance barthesiana), sino también a los procesos de "evocación» que se dan en este tipo de receptores, refiriéndose a la disposición que poseen respecto a impresiones emotivas que se relacionan también con su mundo inconsciente (esto es, con el universo de los deseos, instintos, recuerdos o miedos). Esta implicación emocional del receptor en el proceso de lectura 
del texto fílmico es otro de los elementos que en este trabajo hemos considerado, de hecho, como poéticos.

Escribir un poema, así como escribir un guion para el cine, es más que escribir. Tal vez sea escribir con silencios y miradas, con movimientos y pausas que ponen en acción un complejo universo de imágenes y sonidos que podrían establecer un sinnúmero de relaciones entre sí, jugando con las impresiones o el inconsciente, produciendo ambigüedades o concreciones reales, provocando formas invisibles en nuestra imaginación o en nuestras retinas, que rechazamos o abrazamos en plena sintonía (Amar 2003, 434-435).

Además, lo que el cine ha propuesto como característica novedosa ha sido la destrucción del principio de continuidad, creando la discontinuidad dentro del arte visual, que se expresa a través de algunos elementos concretos, como la elipsis. En este trabajo hemos considerado la naturaleza fragmentaria del cine como un nexo más que lo emparenta con la poesía y esta actúa de la misma forma, generando la unidad del poema solo a partir de una estructura fragmentaria, con unos versos que presuponen continuas pausas y cesuras. Este es otro elemento que hace que consideremos el lenguaje cinematográfico y el lenguaje poético como lenguajes vinculados entre sí, incluso complementarios. La narrativa literaria en prosa se separa del cine en este punto, ya que lo que garantiza al lector la comprensión y aceptación del pacto ficcional es esencialmente una continuidad estilística en la escritura que, respecto al cine, solo encontramos dentro del guion: las imágenes montadas en una película no aseguran la fluidez de un "cuerpo" que en realidad aparece desmontado y fragmentario, fragmentariedad que sí hallamos también en la poesía y en su manifestación escrita más común, el poema en verso o prosa.

Entonces, la posibilidad por parte de la poesía y del cine "poético« de producir miradas silenciosas, pausas, elipsis, vacíos y las propias ambigüedades que acabamos de considerar, constituye también una de las claves teóricas de nuestro trabajo. Estas ambigüedades se relacionan con la posibilidad por parte de este cine y de la poesía de crear unos sentidos ambiguos en los receptores y, por ello, diversos, dispares, logrando que cada acto de interpretación sea único. Además, Amar subraya el hecho de que la empatía, la emoción y el talento son elementos que se encuentran como común denominador entre poesía y cine, porque ambas buscan la estimulación de los sentidos y la percepción del placer (Amar 2003, 434435). Con esto, Amar se refiere esencialmente al hecho de que la plurisignificación o ambigüedad es una parte esencial del lenguaje cinematográfico y poético. El cine y la poesía serían dos artes que se corresponden y se complementan. Estas dos artes se basan en el "comprender" sintiendo y en 
el sentir aprendiendo, y ambas tienen la capacidad de provocar un cierto encantamiento; este poder cautivador y fascinador, en el caso del cine, se acentúa aún más por las condiciones materiales que rodean al proceso de recepción, como puede ser la oscuridad de la sala, el sonido, la disposición de las butacas o la grandiosidad de la pantalla.

\section{REFERENCIAS BIBLIOGRÁFICAS}

AmAr, Victor. 2003. «Poesía y cine: un ensayo sobre la palabra y la imagen». Ámbitos, n. ${ }^{\circ} 910$, pp. 429-437.

BORDWELl, David. 1996. La narración en el cine de ficción. Barcelona, Paidós.

Deleuze, Gilles. 1984. La imagen-movimiento. Barcelona: Paidós.

Deleuze, Gilles. 1987. La imagen-tiempo. Barcelona: Paidós.

DostolevskiJ, Fedor. 2007. Le notti bianche. Roma: Il Filo.

Lotman, Jurij Michajlovic y Yuri Tsivian. 2000. Diálogo con la pantalla. Bérgamo: Moretti \& Vitali.

Monegal, Antonio. 1993. Luis Buñuel de la literatura al cine. Una poética del objeto. Barcelona: Anthropos.

Pasolini Pier Paolo y Éric RoHmer. 1970. Pier Paolo Pasolini contra Eric Rohmer: Cine de poesía contra cine de prosa. Madrid: Alianza Editorial.

TALENS, Jenaro. 2002. Negociaciones para una poética dialógica. Madrid: Biblioteca Nueva.

TALENS, Jenaro. 2010b. El ojo tachado. Madrid: Cátedra.

TARKOWSKY, Andrei. 2005. Esculpir el tiempo. Madrid: Rialp.

ZunZunEGuI, Santos. 2002. "Críticos al borde de un ataque de nervios. "Realismo" y "realismos" en el cine español». Cuadernos de la Academia, n. ${ }^{\circ} 11-12$, pp. $471-483$.

\section{Filmografía}

Noches blancas (Notti bianche). Dirección: Luchino Visconti. Actores: Maria Schell, Marcello Mastroianni, Jean Marais, Marcella Rovena, Maria Zanoli, Elena Fancera. Vides Cinematografica / Intermondia Films, 1957. 